\title{
Identifying Teaching Writing Strategies Used by English Teachers at SMK N 3 Singaraja During Remote Teaching
}

\author{
Ni Nengah Diah Handayani ${ }^{1}$ \\ Universitas Pendidikan Ganesha, Indonesia \\ diahhandayannii@gmail.com \\ Putu Eka Dambayana Suputra ${ }^{2}$ \\ Universitas Pendidikan Ganesha, Indonesia \\ ekadambayana@gmail.com \\ Putu Adi Krisna Juniarta ${ }^{3}$ \\ Universitas Pendidikan Ganesha, Indonesia \\ adi.krisna@undiksha.ac.id
}

\begin{abstract}
The current study was carried out to identify the teaching writing strategies in remote teaching setting. This study was a case study. The study was conducted at SMK N 3 Singaraja. The participants of the current study were $X$ grade English teachers of the 2020-2021 academic year, which consist of four teachers (2 females and 2 males). In conducting the study, observation and interview guide were used. The data were analyzed with guidance of analyzing qualitative data by Miles, Huberman, \& Saldana (2014). The findings showed that the teaching writing strategies implemented by English teachers were guided writing, mind mapping, scaffolding, and dictogloss. In this remote teaching setting, English teachers are encouraged to be more creative in designing instruction and carrying the teaching strategies for teaching writing. Further study is suggested to identify teaching strategies used by English teacher in remote teaching for different language skills.
\end{abstract}

Keywords: Remote Teaching, Teaching Strategies, Writing

\section{INTRODUCTION}

At the end of 2019 and beginning of 2020, the world experiences a huge change. The existence of the corona virus has greatly changed the face of life in the world. This virus affects many aspects of human life such as economics, social, and education. The government has suggested that people should decrease face to face interaction and stay at home. This thing definitely affects the education. In term of the education, it changes the process of teaching and learning into an online-based teaching. Learning that is usually done at school, now turns into online-based learning for particular reasons (Altunay, 2019). In this case, teachers and students no longer come to school to do the learning process, but they can do it at home.

This learning model is widely known by remote teaching setting. In remote teaching context, the teaching and learning process occurs virtually. This learning is defined as learning carried out from a distance assisted by electronic devices, for instance tablets, smart phones, laptops, and computers which require internet connection (Atmojo \& Nugroho, 2020). The teaching and learning material are 
delivered through various platforms such as web, WhatsApp, Zoom, Webinar, etc. Those platforms enable the sharing of various types of resources, such as documents, websites and audiovisual materials (Carolan \& Kyppö, 2015). It also offers various interactive functions, such as chatting, a diary, a collaborative writing platform and commenting and feedback functions. Hence, the teaching and learning process in emergency remote teaching are helped by technological devices and software.

In the implementation of online-based remote teaching, many things need to be prepared and considered in order to support the learning process. Teachers must have knowledge and experience in conducting online learning processes so that they are able to help students achieve their learning goals (Hung, 2015). Internet availability is also an important factor in implementing the learning process (Martin et al., 2019). In addition, teachers must also know the readiness of students in the remote teaching process both in terms of mental and financial. Many studies show that online teaching and learning process is often constrained by limited internet quota, slow internet speed, and limited student economics to own a gadget or laptop (Gillett-swan, 2017; Qureshi \& Yasmin, 2012). Thus, in implementing online-based teaching and learning, the readiness of teachers and students is very important to support the success of the online teaching and learning process.

Teacher should understand that teaching writing includes the activities of practicing, having guidance and giving feedback. This is supported by Wang (2015) who suggests that during the process of teaching writing, the teacher should pay attention to the process of writing that the students should continuously rewrite, revise, and edit their writing in order to improve it. Bayat (2014) mentions the stages are prewriting, drafting, editing, revising, and publishing. Furthermore, the teacher should understand that the process of teaching and learning process in writing needs to be assessed individually among students so that the teacher will be able to know the students learning development in writing (Ariyanti, 2016). It can be stated that teaching writing is a complex thing. The teacher needs to consider many things in order to draw students' best potential especially in writing skill.

In principle, learning in the RT setting occurs not face-to-face in the classroom but occurs virtually. According to Bozkurt and Sharma (2020) remote teaching refers to spatial distance, distance education considers distance within the perspective of different angles and strives to explain it through transactional distance. In this setting, teachers are required to devise strategies to ensure the learning environment created is effective. What is learnt is largely dependent on the teachers knowledge base as well as the manner in which content is introduced, explored, and interpreted (Cole \& Watson, 2013). Based on its term, teaching in remote setting can be said similar with distance teaching.

In its application, ERT has several characteristics. ERT can utilize synchronous or asynchronous learning. In synchronous learning, Teacher and student interactions occur simultaneously with the help of video conferencing (Shahabadi \& Uplane, 2015). While in asynchronous learning, communication between teachers and students does not occur directly like learning in the classroom and students can work by their own time and pace (Perveen, 2016). The learning material in asynchronous learning is delivered online for on demand access and the students can engaged with the learning material by their own time 
and schedule (Daniel, 2020). It can be said that in teaching writing through remote setting, the teachers are offered with synchronous and asynchronous model.

Guasch \& Espasa (2015) reviewed that in teaching writing online, using collaborative writing and automatic feedback is highly suggested. In collaborative writing, the students can work together online with their peer to construct ideas and developed it into meaningful paragraph. Meanwhile, uutomatic feedback is able to promote discussion amongst students and enable them to amend their texts accordingly. In this regard, feedback should be epistemic and suggestive; i.e., based on questions and proposals on how writers can improve their assignments, in order to contribute to higher quality student learning. In teaching writing in online environment, it is essential for students to receive support, including feedback, both from their teachers and their peers, so that they are better able to handle the processes and products of academic communication.

Strobl (2015) investigated the effect of instructional support methods on computer supported collaborative synthesis writing. The study was carried out in an 12 writing class at a university college. The participants $(n=42)$ are third-year bachelor students of an applied languages program. The study reveals the usefulness of both scripting and observational learning as instructional support methods for online collaborative synthesis writing in higher education. The quantitative analysis supports most of the posited hypotheses regarding collaboration intensity and efficiency, and the episodes selected from the qualitative analysis provide evidence for the effectiveness of collaboration

As mentioned before, teacher should be ready for the learning process for remote teaching. In this case, teaching strategy definitely becomes one of the most important things in the implementation of remote teaching. Whether it is for reading, listening, speaking, or even writing, teacher needs to use proper teaching strategy for the learning process. As one of the complex skills that must be mastered in English class, the approach to teaching writing skills in remote teaching situations is very different from face-to-face learning situations. The strategies used by the teacher must adjust to the current conditions. Usually teaching writing skills is done by mentorship strategy (Cheung, 2018). In this strategy, the teachers asked students to write something based on the teacher's direction and then the teachers will give input or scores directly. Indeed, this strategy cannot be applied in this remote teaching setting. Teaching writing in remote teaching setting should focus on helping the students to present and support arguments, acknowledge source of the ideas presented in the text, be able to shift from informal to formal language (Carolan \& Kyppö, 2015). Besides that, they also mention that the process of teaching writing should incorporate three other highly important skills: responding (sharing), evaluating, and postwriting which comprise re-reading the text for the logical structures and cohesion, eliminating the redundant text and proofreading for spelling, grammar and vocabulary. It can be said that teaching writing in classroom setting and online setting is different. The teachers are required to make adjustment to the current situation.

Initial observations were conducted at SMK N 3 Singaraja to find out the conditions of English teaching and learning especially in writing. The curriculum used at SMK 3 Singaraja is the 2013 curriculum. English is taught at every grade level. SMKN 3 Singaraja has implemented remote teaching since the government issued a policy on learning from home. According to the English teachers, the 
learning interactions use the WhatsApp application. The process of learning writing is currently done by giving assignments to students to record the activities they do during the pandemic condition. The teacher also said that students could consult about their work with both friends and teachers. In addition, the teacher also realizes that the writing learning process has not been maximized because of very different learning situations.

Looking at the current learning situation, it is very interesting to see how the teacher does the teaching and learning process of English especially in writing. Therefore, the current strategy is intended to explore the teaching writing strategy used by English teacher in SMKN 3 Singaraja in remote teaching setting

\section{METHOD}

\section{Design}

This study was a case study. A case study is a type of qualitative study that focuses on exploring certain phenomenon, individual or groups. A case study describes the characteristics as well a description of the discovery (Starman, 2013). In this study, the case study used to explore the teaching writing strategies implemented by English teachers at SMK N 3 Singaraja during remote teaching. In conducting the study, observation and interview were primary used in collecting the data. Data in this study were explained descriptively and analyzed in order to answer questions or problems of this study.

\section{Setting and Participants}

The study was conducted at SMK N 3 Singaraja which is located at Jl. Gempol, Banyuning, Singaraja. The participants of the current study were X grade English teachers of the 2020-2021 academic year, which consist of four teachers ( 2 females and 2 males). The teachers were chosen as participants of the study due to their willingness to be the subject of the study. Moreover, they have considered as professional teachers who have worked as an English teacher for a dozen years and were permanently appointed as State Civil Administration Servant by employment supervisory officer to hold a governmental position.

Those four teachers, in this study, were addressed as Teacher 1 until Teacher 4. Teacher 1 was a female teacher who has worked as a teacher for 15 years and she taught English at X TKJ 3. The second teacher, called Teacher 2, was a male teacher who has worked for 17 years in education field and taught X DPIB 1. Teacher 3 , on the other hands, was a female teacher who has worked for 16 years and she taught X TBSM 2. The last teacher called as Teacher 4 was a male teacher who has worked as a teacher for 16 years and taught X TKJ 1 in this study.

\section{Data Collection and Analysis}

In collecting the data, two instruments, namely observation sheet and interview guide, were used in this study. In doing observation, an observation sheet was used to help recording the interaction between teachers and students in emergency remote teaching setting. Thus, the strategy used by teachers to teach writing during remote teaching can be identified by analyzing the recording. The second instrument was interview guide. The goal of the interview was to ensure which strategy used by teachers, to identify how the teachers implement the strategy in teaching writing and how they see the strategy could improve 
students' writing skill. In conducting the interview, this study used a semistructured interview (SSI). A semi-structured interview was conducted conversationally with the teacher at a time, the SSI employs a blend of closedand open-ended questions, often accompanied by follow-up why or how questions (Adams, 2015). In this research, the semi-structured interview was conducted by phone using closed questions. It was conducted on phone because of the governments' regulation on physical and social distancing in COVID-19 outbreak. The questions developed in the interview were based on a SWOT analysis. A SWOT analysis evaluates the internal strengths and weaknesses, and the external opportunities and threats in an organization's environment. The internal analysis is used to identify resources, capabilities, core competencies, and competitive advantages inherent to the organization (Sammut-Bonnici \& Galea, 2014). However, over time, this analysis is widely used in education as a form of teacher evaluation (Nekoueizadeh et al., 2016). This analysis can be used to determine how effective the instructions carried out by the teachers in the teaching and learning process. In this study, the analysis was the writing teaching strategy used by the teachers.

The data both from the interview and observation were analyzed with guidance of analyzing qualitative data by Miles, Huberman, \& Saldana (2014). According to them, there are five steps of analyzing the data, namely data collection, data reduction, data display and drawing conclusion and verification.

\section{FINDINGS \& DISCUSSIONS}

In order to identify the teaching strategies used by teachers in writing class, observation was conducted eight times. It was eight meetings in which each teacher had two meetings. Then, each teacher used only one lesson plan for two meetings. Thus, there were four lesson plans in total were used in this study. The teaching and learning process was done online assisted by WhatsApp due to the pandemic. Based on the result of the observation on WhatsApp, there were three main writing strategies used by the teachers in SMK N 3 Singaraja as presented in Table 1.

Table 1. The Strategies Used by Teacher in Writing Class

\begin{tabular}{lll} 
No & \multicolumn{1}{c}{ Teaching Strategies } & \multicolumn{1}{c}{ Description } \\
\hline 1 & Guided Writing & $\begin{array}{l}\text { This strategy was used by the teachers to train } \\
\text { writing skills through the teacher's guidance in } \\
\text { the learning process. }\end{array}$ \\
\hline 2 & Mind Mapping & $\begin{array}{l}\text { This strategy was used by the teacher to } \\
\text { improve writing skills by composing the point of } \\
\text { an idea. }\end{array}$ \\
\hline 3 & Scaffolding & $\begin{array}{l}\text { This strategy was used by the teacher to } \\
\text { produce a good writing after conducting several } \\
\text { steps. }\end{array}$ \\
\hline 4 & Dictogloss & $\begin{array}{l}\text { This strategy was used by the teacher to train } \\
\text { students in writing a text based on the given } \\
\text { example. }\end{array}$
\end{tabular}


Table 1 showed that there were four main strategies used by the teacher in teaching writing, namely guided writing, mind mapping, scaffolding, and dictogloss. Based on the result of the observation on WhatsApp, it could be seen that both teachers and students involved actively during writing class. The explanation of the strategies could be seen as follows.

\section{Guided Writing}

This strategy was used by the teacher in teaching recount text. The teacher helped students to make their text. Here, the teacher gave guidance to the students in writing practice. In this strategy, the teacher gave an example of the real text to be read. From this text, the students were asked to identify text. After that, the students were guided to make similar text. The teacher guided students until they produce the expected text.

\section{Mind Mapping}

This strategy was used by the teacher in writing class. It was used to teach recount text. In this strategy, the teacher emphasized the students to determine some points before making the text. The students drew their point on the paper. Then, students elaborated their points to form a sentence even a paragraph.

\section{Scaffolding}

This strategy was used by the teacher to train students' writing skills. In this strategy, students followed some steps of the writing process. The students passed step by step all the stages of writing process.

\section{Dictogloss}

This strategy was used by the teacher to make students active in the writing process. Here, the Teacher 1ssisted students to produce similar text based on the previous example given by the teacher. The students were asked to make a note so that they could compose similar text.

Regarding to the implementation of teaching writing strategies, observation and interview was conducted in order to find the data. First of all, observation was conducted, then, it was followed by interview with the teachers through phone. Table 2 presents the procedure of teaching writing strategies that were implemented by English teachers.

Table2. The Implementation of Strategies Used by Teacher in Remote Teaching

\begin{tabular}{llll} 
No & $\begin{array}{l}\text { Teaching } \\
\text { Strategies }\end{array}$ & & \multicolumn{1}{c}{ Procedure } \\
\hline 1 & Guided & 1. & Asking and explaining past experience. \\
& Writing & 2. & Giving the example and asking the text structure. \\
& & 3. & Asking students to make their text in seven sentences. \\
& 4. & Conducting peer correction \\
& 5. & Revising student's work \\
& 6. & Submitting student's work to the teacher \\
& &
\end{tabular}




\begin{tabular}{|c|c|c|}
\hline 2 & $\begin{array}{l}\text { Mind } \\
\text { Mapping }\end{array}$ & $\begin{array}{l}\text { 1. Asking the definition of recount text } \\
\text { 2. Explaining recount text, simple past tense, and mind } \\
\text { mapping. } \\
\text { 3. Showing the example mind mapping } \\
\text { 4. Explaining and confirming the structure of mind mapping } \\
\text { 5. Making mind mapping from the provided text } \\
\text { 6. Giving feedback. } \\
\text { 7. Giving task }\end{array}$ \\
\hline 3 & Scaffolding & $\begin{array}{l}\text { 1. Asking about recount text } \\
\text { 2. Explaining recount text } \\
\text { 3. Giving an example of simple past tense } \\
\text { 4. Making a list of activities in } 20 \text { minutes } \\
\text { 5. Pointing out one of the students' work } \\
\text { 6. Asking students to make a paragraph } \\
\text { 7. Doing peer correction } \\
\text { 8. Revising students' work based on the given comment } \\
\text { 9. Submitting the task }\end{array}$ \\
\hline 4 & Dictogloss & $\begin{array}{l}\text { 1. Doing listening practice } \\
\text { 2. Asking students to take a note about the spoken text. } \\
\text { 3. Asking students to answer the questions based on the } \\
\text { spoken text } \\
\text { 4. Discussing the answer to the given five questions. } \\
\text { 5. Rewriting story based on the notes in } 30 \text { minutes } \\
\text { 6. Submitting the text }\end{array}$ \\
\hline
\end{tabular}

Table 2 showed that there were four strategies used by the teacher in writing class. First, the guided writing strategy was conducted into seven steps. Second, the mind mapping strategy was conducted into six steps. Third, the scaffolding strategy was conducted into nine steps. The last, dictogloss strategy was conducted into six steps. The explanation of the steps of strategy could be seen as follows.

\section{1) Guided Writing}

In this teaching and learning process, Teacher 1 taught recount text at the tenth grade in SMK N 3 Singaraja. Teacher 1 applied a guided writing strategy to help the students in writing the text. This strategy was applied in two meetings. There were seven main steps conducted by Teacher 1 using guided writing in teaching recount text as follows. At the beginning of the meeting, Teacher 1 greeted the students and checked their attendance. Then, it was continued to the topic of the lesson.

Figure 1 Guided Writing Implementation 
The Art of Teaching English as a Foreign Language, Vol.1 No.2 2020

p-ISSN : 2656-8942, e-ISSN : 2684-8546

DOI: $10.36663 /$ tatefl.v1i2.79

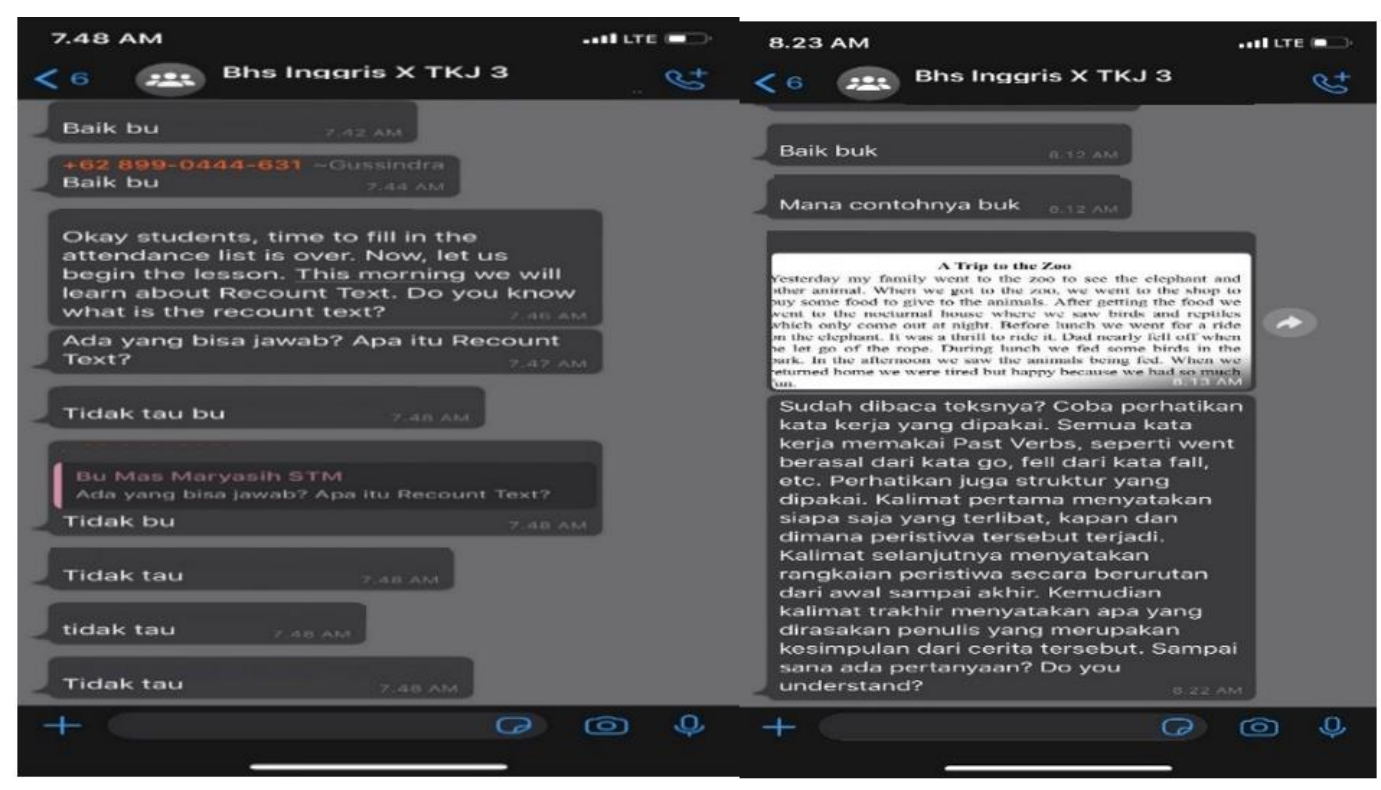

Figure 1 showed that Teacher 1 asked students about recount text to her students. She said 'Do you know what is the recount text?' After that, students started to respond to their teacher's question. Most of students did not know about recount text. Teacher 1 gave an example of recount text. Teacher 1 asked the students to pay attention on the given example. After discussing the example of the text, Teacher 1 emphasized the structure of recount text in general which included the use of verb II to inform past event. Teacher 1 asked students whether or not they understood the material. Here, Teacher 1 asked students to make a simple recount text which consisted of seven sentences. Teacher 1 gave 30 minutes to do the task. During the writing process, Teacher 1 asked if the students could finish before the set time. Teacher 1 gave a brief explanation about the form of the verb during a discussion. Teacher 1 reminded the use of verb II in writing recount text. Moreover, Teacher 1 also gave some examples of the verb form like eat became ate, drink became drank and play became played. The students could use their dictionary to find the form of the verb. After finishing the work, Teacher 1 asked the students to revise their works based on the given comment from their partner in 20 minutes.

The teacher gave the students chance to work independently. The teacher only assisted when students faced problems in learning. The teacher gave an example at the beginning of the lesson. This example was used to guide students in writing class. It was in line with Umpa et.al (2019) where the example guided students to experience the writing process. Teacher 1 had conducted peercorrection in the writing process. Holdich \& Chung (2003) support that guided writing allowed students to experience the writing process like connecting words and sentences in forming a text as well as helping students to describe a text. In guided writing, students discovered their knowledge in learning. In line with this matter, Martarini \& Sastaparamitha (2020) stated that the step of guided writing directs students to conduct discovery learning where they have to find out the information by themselves. This process directly guided students to obtain as 
much as information they could get from some sources. Thus, students could get the needed information. This strategy was useful for writing skill in which it helped students to improve or even developed their writing skill. The result of the interview with Teacher 1 showed that this strategy was suitable to conduct student-centered learning where the students worked independently. She said:

'This strategy focuses on student center learning. Here, I am as their guide. It guides students to use their knowledge to understand what they learn.'

She also added that the strategy gave students self-correction in making the text. However, the lesson was not maximum due to remote teaching because they had limited time to do exercise. She said

'Students have limited time and guidance in using this strategy'.

In addition, the Teacher 1 could not directly help students face to face. It was in line with Juriah (2015) in which this strategy was lack of time. This strategy wasted too much time and required teacher's effort to conduct learning. In addition, Teacher 1 could not directly help students face to face. Umpa et al., (2019) also argued that guided writing was suitable for writing competency. It helped students to reduce their errors during writing class. The implementation of guided writing in the present study showed that the Teacher 1 asked their student to do peer-correction which helped them to develop their skill as well as improved their work.

2) Mind Mapping

This strategy was used by Teacher 2 in teaching recount text in the tenth grade of SMK N 3 Singaraja. This strategy was conducted in two meetings. Before conducting the teaching and learning process, students were asked to fill the attendance list. Teacher 2 also reminded students to ask him if they found a problem at the meeting. Figure 2 gives explanation on the implementation of mind mapping. 
The Art of Teaching English as a Foreign Language, Vol.1 No.2 2020

p-ISSN : 2656-8942, e-ISSN : 2684-8546

DOI: $10.36663 /$ tatefl.v1i2.79

Figure 2. Mind Mapping Implementation

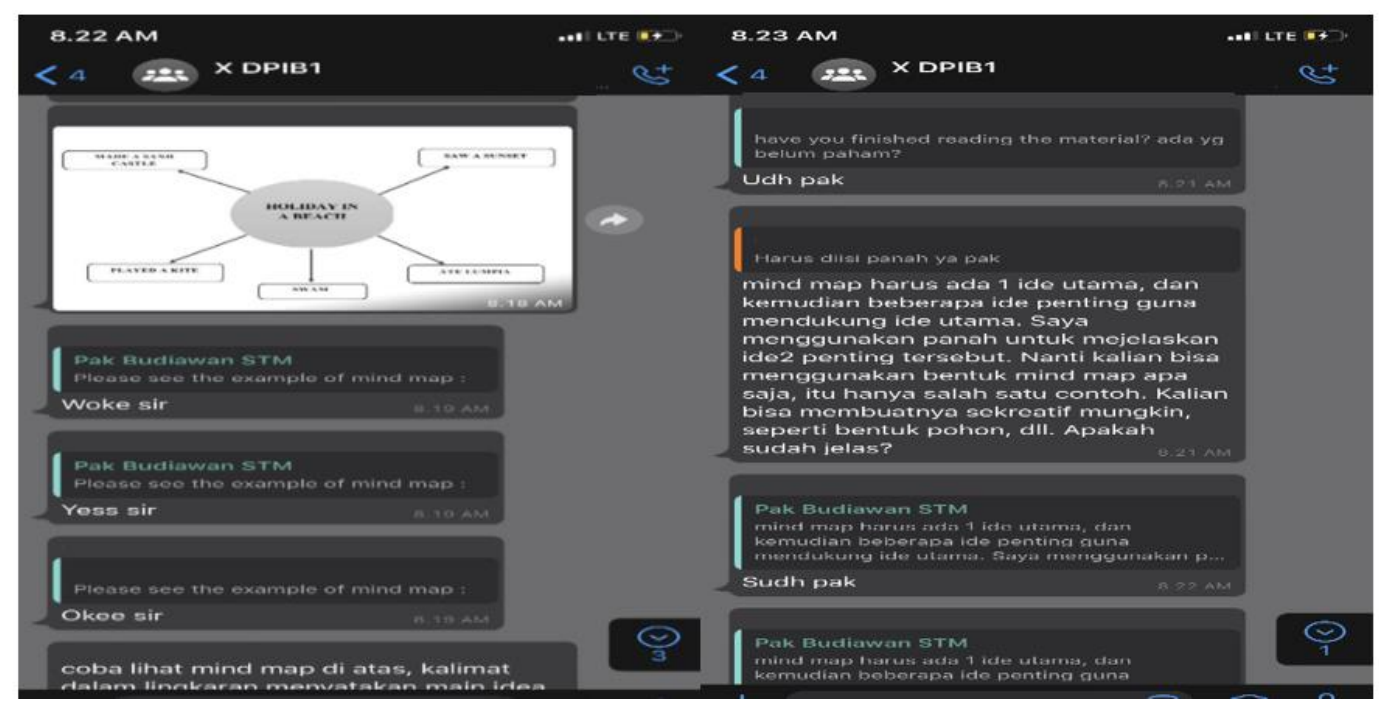

In Figure 2, teacher 2 explained briefly about mind mapping. The students were given an example of mind mapping. The topic was about a holiday on the beach. Teacher 2 asked the students to pay attention on the given example. Teacher 2 guided the students to know the part of the mind mapping. Teacher 2 explained that the circle consisted of main idea of the event. Meanwhile, the rectangles consisted of supporting idea of the event. The mind mapping covered the point of the past event in the form of activities. Teacher 2 explained to the students what should be inserted in the mind mapping. Here, Teacher 2 told that mind mapping consisted of the main idea and supporting the idea. Teacher 2 asked students to create their mind mapping based on their style. The students could make the mind mapping in the form of tree or another form. Teacher 2 gave a task to the students to make their mind mapping based on the given themes. The teacher gave three themes (holiday, school experience, and holy day experience. From the given themes, students were asked to choose one of the themes. Teacher 2 gave next instruction after the students finished their works. That was all the implementation of the mind mapping in writing class.

In mind mapping strategy, Teacher 2 asked students to make mind maps in learning. This activity led students to have a simple way of drafting their idea. In line with Bukhari (2016), mind mapping assisted students to design the idea by making points in the form of a diagram before the writing process. In line with this matter, the result of an interview with Teacher 2 who applied mind mapping in teaching recount text showed that the strategy supported students in the writing process. He said

'students are guided to find out the main point in the text. As the result, students could make their own text based on the mind mapping'

He added that students know what they were going to do by preparing the mind maps. Fadillah (2019) argued that mind mapping gave advantages in learning writing such as easy to be implemented during the teaching and learning 
process, facilitating students to organize students' idea, and helping students to remember idea well. However, for some students in remote teaching, the internet connection became the problem in sending the picture of mind mapping to the teacher. However, for some students in remote teaching, the internet connection became the problem in sending the picture of mind mapping to the teacher. He said

'some students can't send the photo on time because the internet connection does not run well.'

They needed more time to send a photo to the teacher. It was similar with a study conducted by Pratiwi et al., (2016) who found out the time management became the problem in implementing mind mapping. Overall, this strategy was useful for students and teaching to conduct the teaching and learning process.

\section{3) Scaffolding}

This strategy was used by Teacher 3 in teaching recount text for two meetings. Here, the students experienced active writing activities. The description of the steps in conducting a scaffolding strategy could be seen as follows.

Figure 3. Scaffolding Implementation

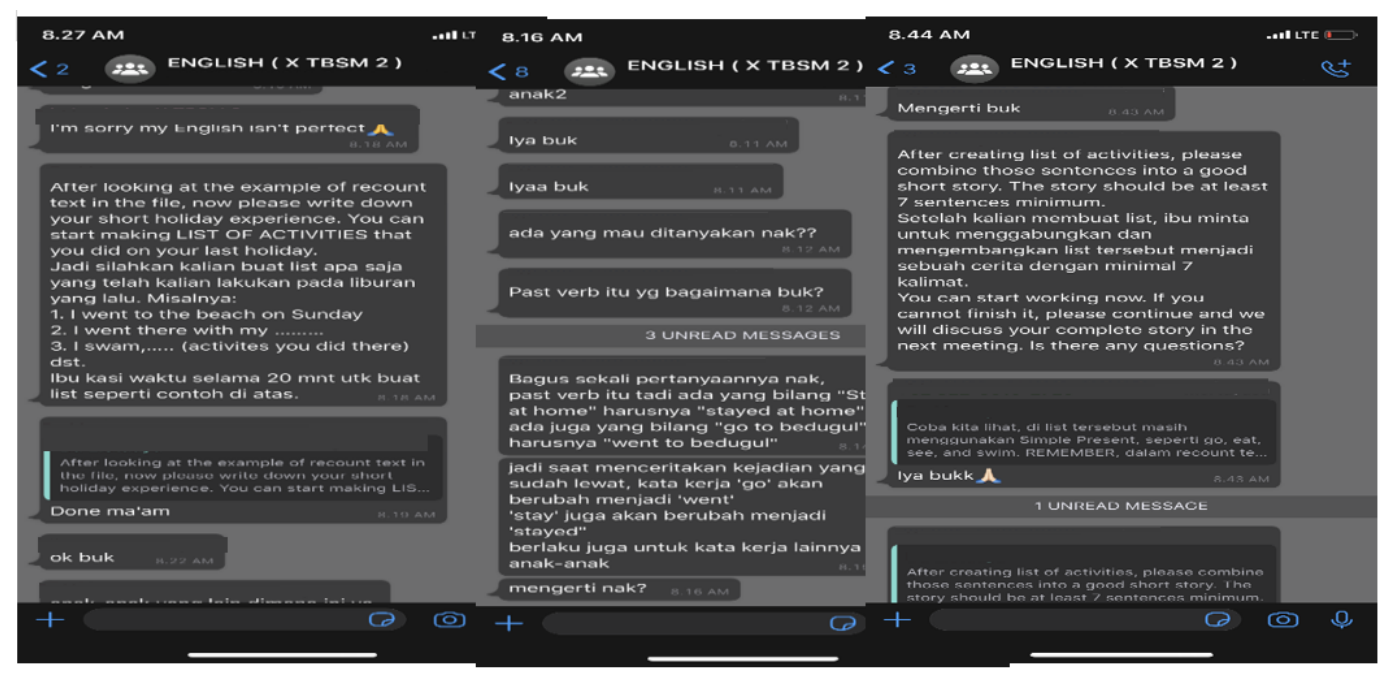

Teacher 3 asked students to make a list of activities on the last holiday. Here, Teacher 3 also gave three examples of activities list. Teacher 3 gave 20 minutes to make the list of activities. After making the list of activities, students were asked to show their works to Teacher 3 . The teacher picked one of the students' works to be discussed. Here, Teacher 3 gave the correction on students' work especially on the form of a verb. After that, students revised their work based on the teacher's explanation. Teacher 3 asked students to make a paragraph based on the created list of activities. Teacher 3 also asked students to develop the list of activities into a story in seven sentences at least. Teacher 3 gave students time to make it. They could continue their works if they had not finished their work. The works were discussed in another meeting. The Teacher 3 asked students to do peer-correction. Here, students were asked to exchange their work 
with their friends to find out some mistakes made by the students. The correction included grammar, spelling, and punctuation of the text. Teacher 3 asked whether or not students still remembered the form of verb in recount text. Since, there were two students gave different answers, Teacher 3 clarified it. After conducting peercorrection, the Teacher 3 asked students to return their friends' work and recheck it. The students were asked to revise their mistakes based on the given comment as suggested by their friends. The students got a chance to ask questions to their teacher to make everything clear.

In scaffolding strategy, the students had followed some steps in writing process. This process guided students to actively participate in the learning. The result of an interview with Teacher 3 showed that this strategy gave a chance to students to involve and join the writing process. She said

'Students learn from the given example, then, they make a draft, conduct editing, revise their work, and submit it to me.'

It also assisted students to do an activity in sequence. As the result, the students knew what to do and how to do it. In line with this matter, Prabandani (2016) argued that the strengths of scaffolding are helping students to understand the given material, assisting students in making a text, and facilitating students understanding. In the dictogloss strategy, students were assigned to produce similar text. The result of an interview with Teacher 4 showed that dictogloss strategy was an effective strategy to teach writing skills. He said:

'this strategy makes students learn naturally from listening at the first step of the learning process. It trains students' skill and I ask students to take a note from text.'

The students could produce a simple similar text. Dictogloss has some advantages, namely as an effective way in individual and group work, facilitating students' communicative competence, promoting vocabulary acquisition, and increasing students' motivation (Dista, 2017). The teacher helped students in guiding students to produce the text.

\section{4) Dictogloss}

This strategy was used by Teacher 4 in teaching recount text. It was done in two meetings. Teacher 4 emphasized the learning process by giving the students some examples and asking students to make a note. The implementation of the dictogloss could be seen as follows. 
Figure 4. Dictogloss Implementation

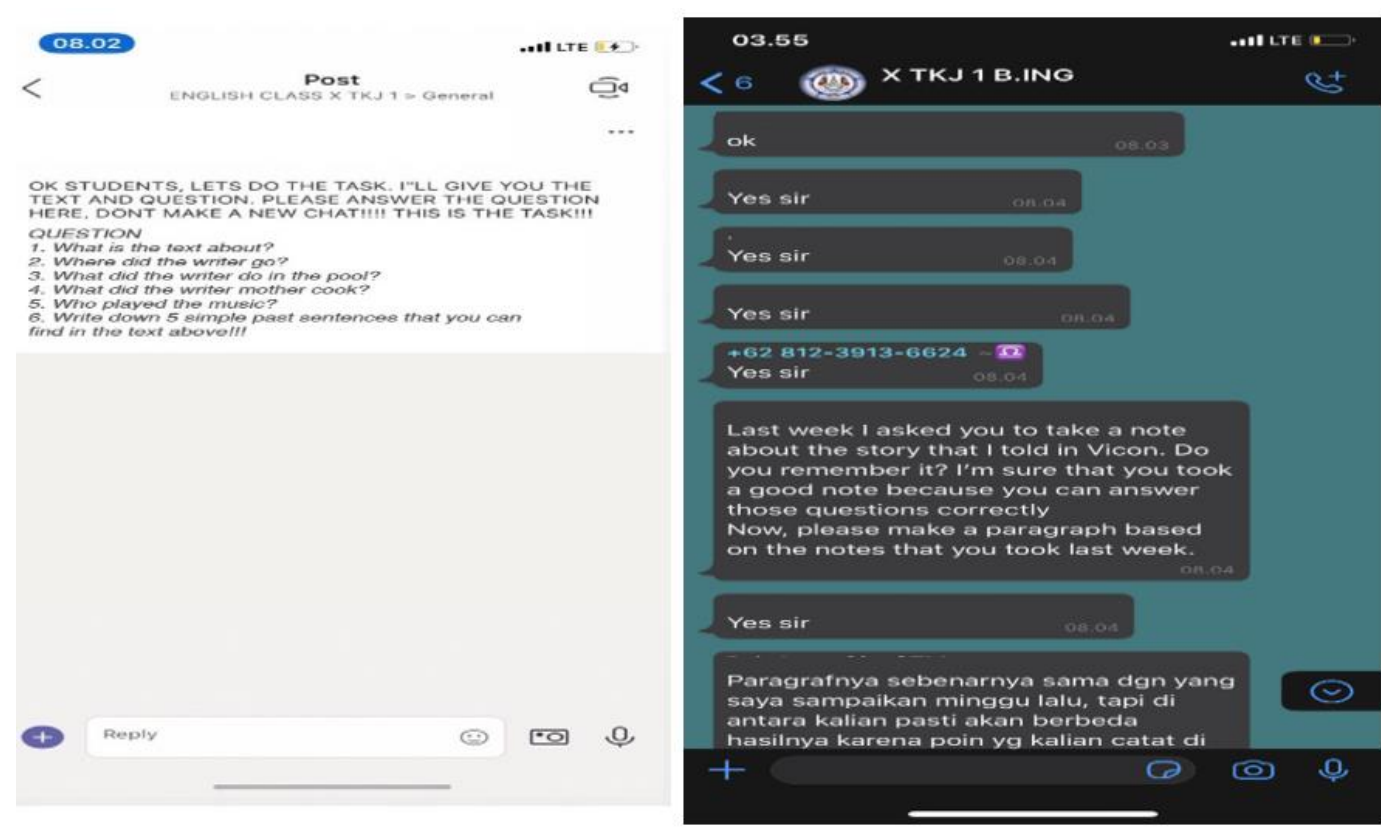

Teacher 4 asked students to answer five questions. After listening to Teacher 4, the students were asked to answer the given questions correctly related to the previous listening session. Teacher 4 discussed the questions with the students. They discussed it one by one. Teacher 4 asked a question and the students answered it. Teacher 4 also gave a feedback after answering the questions. Teacher 4 asked students to rewrite text based on the note that had been made at the previous meeting. At the previous meeting, all students were asked to take a note in listening session. From the note, the students formed a recount text. Teacher 4 gave 30 minutes to make the text. Teacher 4 emphasized that the result of students' work would be different each other depending on their note and elaboration.

In the dictogloss strategy, students were asked to produce similar text based on the teacher's example. The result of an interview with Teacher 4 showed that dictogloss strategy was an effective strategy to teach writing skills. He said

'this strategy makes students learn naturally from listening at the first step of the learning process. It trains students' skill and I ask students to take a note from text.'

The students could produce a simple similar text. The teacher helped students in guiding students to produce the text. However, the teacher faced a problem in conducting due to internet connection where it disconnected to students. He reported:

'I am trying to talk with my students but no one answers me due to a poor internet connection.' 
The teacher needed a lot of time to refresh the connection again before starting the lesson again. In addition, Pertiwi et al., (2018) state that dictogloss gave an effective influence on students' writing skill as well as offer students the opportunity to work in pair or group. In addition, dictogloss is a recommended strategy to conduct an effective teaching in writing process (Pertiwi et al, 2018). Overall, this strategy could be used in remote teaching by providing more time to the learning process.

In summary, the implementation of guided writing, the result of the showed that guided writing was used to make a recount text. This strategy emphasized student-centered learning. Teacher 1 only guided the students by providing them an example of recount text. Teacher 1 assisted them to handle problems. The obstacle in implementing guided writing occurred on the limited time due to remote teaching. It was because the students needed time to understand the material. In order to handle this problem, Teacher 1 designed learning into two meetings. The students were also asked to do peer correction. Overall, the implementation of guided writing is effective in remote teaching but the maximum can be reached in direct meeting (offline). The results of interview in implementing mind mapping showed that this strategy was effective to make students active in learning. The students were asked to make their mind mapping. Teacher 2 asked the students to send their work of mind mapping in the WhatsApp group. The strength of this strategy was on students' idea. They could find out the points of the information. It assisted students to make their recount text.

During the implementation, internet connection became the problem. The students could not submit the work on time. Teacher 2 gave them time and waited for them. Overall, the strategy worked on students' writing skill especially in recount text. Next, in scaffolding implementation, it showed that the strategy was helpful because the students passed several writing processes. The strength of this strategy focused on the process of writing such as drafting, editing, improving, and submitting the works. The obstacle in implementing this strategy was on the time allotment. The students needed more time to get maximum result. Teacher 3 had limited access to every student in the online group. To cover this problem, Teacher 3 helped students who faced problem in writing their text. From the process, this strategy was effective in recount text as long as the time allotment was managed. In dictogloss, the learning emphasized on listening practice. Teacher 4 asked the students to listen their teacher in reading a text. Then, the students were asked to take a note from the listening practice. On the other hand, the problem emerged due to internet connection. Teacher 4 could get students' respond for a while because the connection was low. Teacher 4 needed to wait the students' respond. As the result, Teacher 4 handled this problem by repeating the text twice. From the process, this strategy was effective to train students' skill both in listening and writing. The students were active in learning process. As the result, the students could create their text. In summary, the result of interview showed that those strategy could be used in remote teaching.

This study implies that four teaching strategies could be used in remote teaching, namely guided writing, mind mapping, dictogloss, and scaffolding. 
These strategies could guide students to produce their recount text through different processes. The guided writing strategy emphasized the teacher's guidance in the learning process. The mind mapping strategy focused in composing the points of idea before producing a text in writing class. The scaffolding strategy provided students some steps to be done in producing a text. The dictogloss strategy provided the students a text to produce a similar text. The teacher was expected to be a facilitator with the assistance of these strategies.

Based on the findings of implementation, it can be said that the scaffolding strategy is the most suitable strategy in pandemic situation. The students do not have to be present in school in doing their writing and they can still interact with the teacher through WhatsApp if they find difficulties.

\section{CONCLUSION}

Based on the findings and discussion as stated in the previously, the study concludes as follows:

1. There were four strategies used by the teachers in teaching writing during remote teaching namely, guided writing, mind mapping, scaffolding, and dictogloss.

2. There were six stages covered by guided writing and mind mapping. The steps of guided writing were 1) Asking and explaining the definition of recount text: 2) Giving the example of the recount text and simple past tense form.; 3) Asking students to make activities list; 4) Conducting peer correction; 5) Revising student's work; and 6) Submitting student's work to the teacher. The steps of mind mapping were 1) Asking the definition of recount text; 2) Explaining recount text, simple past tense, and mind mapping; 3 ) Showing the example mind mapping; 4) Explaining and confirming the structure of mind mapping; 5) Making mind mapping from the provided text; 6) Giving feedback; and 7) Giving task. The steps of scaffolding were 1) Asking about recount text; 2) Explaining recount text; 3) Giving an example of simple past tense; 4) Making list of activities in 20 minutes; 5) Pointing out one of students' work; 6) Asking students to make a paragraph; 7) Doing peer correction; 8) Revising students' work based on the given comment; and 9) Submitting the task. The steps of dictogloss strategy were 1) Doing listening practice; 2) Asking students to take a note about the spoken text; 3) Asking students to answer the questions based on the spoken text; 4) Discussing the answer of the given five questions; 5) Rewriting story based on the notes in 30 minutes; and 6) Submitting the text.

\section{REFERENCES}

Adams, W. (2015). Conducting Semi-Structured Interviews. In K. Newcomer, H. Hatry, \& J. Wholey (Eds.), Handbook of Practical Program Evaluation (Issue August). Jossey-Bass. https://doi.org/10.1002/9781119171386.ch19

Altunay, D. (2019). EFL Students ' Views on Distance English Language Learning in a Public University in Turkey. Studies in English Language Teaching, 7(1), 121-134. https://doi.org/10.22158/selt.v7n1p121

Ariyanti. (2016). The Teaching of EFL Writing in Indonesia. Dinamika IImu, 16(2), 263-277. https://doi.org/10.21093/di.v16i2.274 
Atmojo, A. E. P., \& Nugroho, A. (2020). EFL Classes Must Go Online! Teaching Activities and Challenges during COVID-19 Pandemic in Indonesia. Register Journal, 13(1), 49-76. https://doi.org/10.18326/rgt.v13i1.49-76

Bayat, N. (2014). The Effect of the Process Writing Approach on Writing Success and Anxiety. Educational Sciences: Theory \& Practice, 14(3), 1133-1142. https://doi.org/10.12738/estp.2014.3.1720

Bozkurt, A., \& Sharma, R. C. (2020). Emergency remote teaching in a time of global crisis due to CoronaVirus pandemic Emergency remote teaching in a time of global crisis due to CoronaVirus pandemic. Asian Journal of Distance Education, 15(1), 1-6. https://doi.org/10.5281/zenodo.3778083

Carolan, F., \& Kyppö, A. (2015). Teaching process writing in an online environment. In J. Jalkanen, E. Jokinen, \& P. Taalas (Eds.), Voices of pedagogical development - Expanding, enhancing and exploring higher education language learning (pp. 13-30). Research-publishing.net. doi:10.14705/rpnet.2015.000285.

https://doi.org/10.14705/rpnet.2015.000285

Cheung, Y. L. (2018). Teaching Writing. In W. A. Renandya \& H. P. Widodo (Eds.), English Language Teaching Today: Building a Closer Link Between Theory and Practice (Issue August 2016). Springer International. https://doi.org/10.1007/978-3-319-38834-2

Cole, K. S., \& Watson, D. (2013). Academic Writing Within An Online Learning Environment : Assessing The Impact Of Peer Evaluation On Lesson. Journal of International Education Research, 9(2), 115-126. https://doi.org/10.19030/jier.v9i2.7717

Daniel, S. J. (2020). Education and the COVID-19 pandemic. PROSPECTS. https://doi.org/10.1007/s11125-020-09464-3

Dista, D. M. (2017). Using Dictogloss To Improve Listening. English Education Journal, 8(2), 149-163.

Fadillah, R. (2019). Students' Perception on the Use of Mind Mapping Application Software in Learning Writing. A Journal of Culture English Language Teaching Literature \& Linguistics, 6(1), 58. https://doi.org/10.22219/celticumm.vol6.no1.58-64

Gillett-swan, J. (2017). Th e Challenges of Online Learning Supporting and Engaging the Isolated Learner. Journal of Learning Design, 10(1), 20-30.

Guasch, T., \& Espasa, A. (2015). CollaborativeWriting Online: Unravelling the Feedback Process. In G. Rijlaarsdam, M. Deane, \& T. Guasch (Eds.), Studies in Writing (pp. 13-30). Brill. https://doi.org/10.1108/s15726304(2011)0000022017

Holdich, C. E., \& Chung, P. W. H. (2003). A "computer tutor" to assist children develop their narrative writing skills: Conferencing with HARRY. International Journal of Human Computer Studies, 59(5), 631-669. https://doi.org/10.1016/S1071-5819(03)00086-7

Hung, M. (2015). Teacher Readiness for Online Learning: Scale Development and Teacher Perception. Computers \& Education, 94, 120-133. https://doi.org/10.1016/j.compedu.2015.11.012

Juriah. (2015). Implementing Controlled Composition to Improve Vocabulary Mastery of EFL Students. Dinamika IImu, 15(1), 139. https://doi.org/10.21093/di.v15i1.200

Martarini, N. M. L., \& Sastaparamitha, N. N. A. J. (2020). The Effect of Guided 
Writing Strategy in Writing Skill. Yavana Bhasha: Journal of English Language Education, 3(2), 44. https://doi.org/10.25078/yb.v3i2.1711

Martin, F., Wang, C., \& Jokiaho, A. (2019). Examining Faculty Readiness to Teach Online: A Comparison of US and German Educators. European Journal of Open, Distance and e-Learning, 22(1), 53-69. https://doi.org/10.2478/eurodl2019-0004

Miles, B., Huberman, M., \& Saldana, J. (2014). Qualitative Data Analysis: A Methods Sourcebook. SAGE Pub.

Nekoueizadeh, M., Bahrani, T., \& Azizi, M. (2016). Considering the SWOT Analysis of Teacher Evaluation by Students. British Journal of Education, Society \& Behavioural Science, 13(4), 1-11. https://doi.org/10.9734/BJESBS/2016/10937

Pertiwi, D., Ngadiso, \& Drajati, N. A. (2018). The Effect of Dictogloss Technique on the Students 'Writing Skill. Studies in English Language and Education, 5(2), 279-293.

Perveen, A. (2016). Synchronous and Asynchronous E-Language Learning: A Case Study of Virtual University of Pakistan. Open Praxis, 8(1), 21-39.

Prabandani, W. N. (2016). Teaching Writing of Descriptive Text by Using Scaffolding Technique. Journal of English Teaching and Research, 1(1), 5358.

Pratiwi, D. I., Faridi, A., \& Hartono, R. (2016). The Implementation of Mind Mapping Strategy to Teach Writing in IELTS Preparation Class. Lembaran IImu Kependidikan, 45(1), 33-41.

Qureshi, I. A., \& Yasmin, R. (2012). Challenges of implementing e-learning in a Pakistani university. Knowledge Management \& E-Learning: An International Journal, 4(3), 310-324.

Sammut-Bonnici, T., \& Galea, D. (2014). SWOT Analysis. In S. C. L. Cooper (Ed.), Wiley Encyclopedia ofManagement (pp. 1-9). John Wiley \& Sons, Ltd. https://doi.org/10.1002/9781118785317.weom120103

Shahabadi, M. M., \& Uplane, M. (2015). Synchronous and asynchronous elearning styles and academic performance of e-learners. Procedia - Social and Behavioral Sciences, 176, 129-138. https://doi.org/10.1016/j.sbspro.2015.01.453

Strobl, C. (2015). Learning to Think andWrite Together: Collaborative SynthesisWriting, Supported by a Script and a Video-based Model. In G. Rijlaarsdam, M. Deane, \& T. Guasch (Eds.), Studies in Writing (Vol. 29, pp. 67-93). Brill. https://doi.org/10.1163/9789004290846

Umpa, J. M., Batalon, M., Guimba, W. D., Tamano, R. G., \& Alico, J. (2019). Writing Error Remediation through Guided Writing Strategy: A Mixed Methods Probe. Journal of Arts, Science \& Commerce, 10(1), 42-59. https://doi.org/10.18843/rwjasc/v10i1/05

Wang, P. (2015). Effects of an Automated Writing Evaluation Program : Student Experiences and Perceptions. Electronic Journal of Foreign Language Teaching, 12(1), 79-100. 